\title{
Peningkatan Kompetensi Guru dalam Pembuatan Video Animasi Pembelajaran Interaktif dengan Powtoon
}

\author{
Irnin Agustina Dwi Astuti ${ }^{*}$, Dasmo ${ }^{1}$, Yoga Budi Bhakti ${ }^{1}$ \\ ${ }^{1}$ Program Studi Pendidikan Fisika, Universitas Indraprasta PGRI, Jl. Nangka Raya No.58 C, Tanjung Barat, Jagakarsa, \\ Jakarta Selatan, Indonesia, 12530
}

*Email koresponden: irnin.agustina@gmail.ac.id

\author{
ARTICLE INFO \\ Article history \\ Received: 09 Jan 2021 \\ Accepted: 01 Mar 2021 \\ Published: 23 Apr 2021
}

\section{Kata kunci: \\ Pelatihan guru \\ Powtoon, \\ Video pembelajaran \\ interaktif}

\begin{abstract}
A B S T R A K
Background: Perilaku inovatif guru sangat dibutuhkan selama pandemi Covid 19 saat ini. Guru dituntut untuk membuat media pembelajaran yang kreatif agar bisa diberikan ke siswa agar siswa tidak jenuh belajar selama belajar di rumah. Tujuan kegiatan pengabdian kepada masyarakat ini untuk untuk meningkatkan kemampuan guru-guru di SMK Paya Rumput Melaka Malaysia dalam pembuatan video animasi pembelajaran interaktif dengan Powtoon. Metode: Mitra dalam kegiatan pengabdian masyarakat ini adalah SMK Paya Rumput Melaka Malaysia dengan jumlah peserta sebanyak 59 guru. Metode yang digunakan dalam kegiatan Pengabdian Kepada Masyarakat meliputi wawancara, sosialisasi, dan pelatihan. Pengambilan data dilakukan dengan penyebaran angket secara online melaui google form. Hasil: Berdasarkan analisis data diperoleh peningkatan guru dalam pembuatan video animasi pembelajaran dengan Powtoon sebesar $39 \%$. Guru sangat antusias mengikuti kegiatan pelatihan. Kesimpulan: Kegiatan pengabdian kepada masyarakat berjalan dengan lancar dan mampu memberikan respon yang positif dari guru-guru di SMK Paya Rumput Melaka Malaysia.
\end{abstract}

\section{A B S T R A C T}

Background: Innovative teacher behavior is urgently needed during the current Covid 19 pandemic. Teachers are required to create creative learning media to be given to students so that students are not saturated with learning while studying at home. This community service activity aims to improve teachers' ability at SMK Paya Rumput Melaka Malaysia to make interactive learning animation videos with Powtoon. Method: The partner in this community service activity is SMK Paya Rumput Melaka Malaysia, with 59 teachers. Methods Used in Community Service activities include interviews, socialization, and training. Data collection is done by spreading the questionnaire online through a google form. Result: The data analysis obtained an increase in teachers in the creation of animated video learning with Powtoon by $39 \%$. Teachers are very enthusiastic about participating in training activities. Conclusion: Community service activities went smoothly, and we were able to give a positive response from the teachers at SMK Paya Rumput Melaka Malaysia.

(C) 2021 by authors. Lisensi Jurnal Solma, UHAMKA, Jakarta. Artikel ini bersifat open access yang didistribusikan di bawah syarat

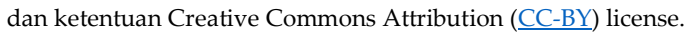

\section{PENDAHULUAN}

Pada zaman modern seperti sekarang ini, kemajuan teknologi di bidang informasi dan komunikasi terus meningkat. Saat ini semua orang dapat memperoleh segala informasi hanya dengan mengakses internet. Terlebih lagi, perkembangan internet diimbangi dengan 
perkembangan perangkat keras atau pun perangkat lunak serta banyak nya aplikasi yang bertujuan untuk memudahkan pekerjaan sehari-hari baik di bidang pendidikan, perkantoran, dan lainnya (Martha et al., 2018).

Pada tahun 2020, semua kalangan baik sektor kesehatan dan pendidikan terdampak karena adanya pandemi Covid 19. Untuk memutus mata rantai Covid-19, Sekolah terpaksa melakukan pembelajaran jarak jauh menggunakan model online sebagai pengganti hingga batas waktu yang belum ditentukan. Kondisi ini secara turunan mengharuskan seluruh pemangku kepentingan yang terlibat dalam pendidikan, khususnya guru, untuk beradaptasi sehingga tujuan mutu dan pembelajaran dapat tercapai dengan baik. Perilaku inovatif guru sangat dibutuhkan selama pandemi Coronavirus disease 19 (Covid-19) untuk membuat suasana belajar siswa tidak monoton dan menyenangkan selama belajar di rumah (Asmuni, 2020).

Dalam kondisi ini, inovasi menjadi salah satu kunci untuk menyelesaikan permasalahan yang ada. Inovasi akan memiliki peran penting dalam pemulihan setelah virus corona (Solviana, 2020). Berbagai negara di seluruh dunia telah memperkenalkan berbagai solusi selama pandemi untuk memberikan proses pendidikan. Hasil penelitian yang dilakukan Purandina menunjukkan bahwa perpustakaan online, siaran TV, pedoman, sumber daya, kuliah video, saluran online diperkenalkan di setidaknya 96 negara selama COVID-19 (Purandina, 2020). Belajar seperti ini tentu telah berubah secara masif kebiasaan yang ada dari proses belajar mengajar.

Berdasarkan wawancara dengan beberapa guru di Sekolah SMK Paya Rumput Melaka Malaysia diperoleh beberapa masalah yaitu 1) guru masih belum terbiasa dalam membuat media pembelajaran berbasis teknologi, 2) guru kurang memanfaatkan sarana dan prasarana yang ada di sekolah. Dalam proses pembelajaran di sekolah saat pandemi seperti ini pihak sekolah menggunakan google classroom untuk akses pembelajaran. Namun hal tersebut terlihat monoton karena hanya menggunakan satu media saja. Oleh karena itu diperlukan suatu inovasi pembelajaran khususnya dalam media pembelajaran yang mendukung pembelajaran online di masa pandemi Covid-19 saat ini.

Inovasi adalah tindakan memperkenalkan praktik baru atau membuat perubahan untuk meningkatkan efektivitas organisasi (Gumanti, 2020). Dalam hal ini, saat ini, guru tidak hanya bertanggung jawab mengajar siswa tentang pengetahuan, keterampilan, dan sikap dengan silabus standar yang ditetapkan oleh Kementerian, tetapi juga didorong untuk inovatif dalam mengajar. Terlebih lagi di masa Pandemi Covid 19 saat ini, guru harus bisa meningkatkan inovasi dalam membuat media pembelajaran yang tepat (Atsani, 2020).

Pada saat Pandemi Covid 19 perilaku inovatif guru terkait erat dengan penguasaan teknologi. Salah satu inovasi media pembelajaran yang bisa digunakan yaitu video animasi pembelajaran dengan Powtoon. Salah satu kelebihan dari video yakni dapat memperkaya penyajian atau penjelasan secara efektif dan efisien (Munir, 2015). Guru dapat menggunakan beberapa aplikasi yang dapat disajikan dalam bentuk video, diantaranya yaitu aplikasi Powtoon. PowToon merupakan aplikasi berbasis web yang disediakan bagi pengguna untuk membuat video animasi dengan memanipulasi benda, gambar impor, menyediakan musik dan pengguna dapat menambahkan suara (Awalia et al., 2019). Video animasi dengan powtoon dapat meningkatkan 
minat belajar siswa, karena di dalam video berisi animasi-animasi yang dapat menjelaskan materi secara jelas dan lengkap (Astika et al., 2019).

Guru harus yakin dengan kemampuan mereka dan memahami inovasi dan mendukung penerimaan teknologi jika ingin mempertahankan tingkat pengetahuan dan keterampilan yang tinggi yang diperlukan untuk mengajar siswa dan mengembangkan keterampilan mengajar mereka menggunakan pendekatan modern untuk belajar menjadi pemimpin dalam implementasi teknologi. Berdasarkan latar belakang masalah tersebut maka dilakukan kegiatan pengabdian kepada masyarakat dengan judul "Peningkatan Kompetensi Guru dalam Pembuatan Video Animasi Pembelajaran Interaktif dengan Powtoon". Tujuan kegiatan pengabdian masyarakat ini untuk meningkatkan kemampuan guru-guru di SMK Paya Rumput Melaka Malaysia dalam pembuatan video animasi pembelajaran interaktif dengan Powtoon sehingga dapat digunakan sebagai pendukung dan bahan ajar dalam pembelajaran Online.

\section{MASALAH}

Berdasarkan penjelasan dari analisis situasi, maka perumusan masalahnya adalah sebagai berikut 1) sarana dan prasarana yang tersedia belum digunakan secara maksimal, 2) guru kurang memanfaatkan teknologi dalam proses pembelajaran, dan 3) kurangnya inovasi media pembelajaran yang digunakan oleh guru.

Berdasarkan permasalahan yang dimiliki oleh mitra, maka perlu dilakukan kegiatan pengabdian masyarakat yang bertujuan untuk meningkatkan kompetensi guru dalam membuat video animasi. Program kegiatan tersebut dilaksanakan guna menyelesaikan masalah yang dihadapi oleh mitra. Untuk mengoptimalkan sarana dan prasarana yang tersedia, maka tim abdimas akan memanfaatkan sarana dan prasarana dengan baik dengan cara memberikan sosialisasi tentang pemanfaatan sarana dan prsarana untuk menunjang proses pembelajaran dengan media pembelajaran interaktif. Untuk mengatasi kelemahan guru dalam memanfaatkan teknologi dalam proses pembelajaran, maka kami tim abdimas akan melakukan pelatihan pembuatan video animasi pembelajaran interaktif. Tujuan dari kegiatan ini adalah agar guru mampu membuat video animasi pembelajaran interaktif yang sederhana dan mudah digunakan dengan menggunakan Powtoon.

\section{METODE PELAKSANAAN}

Metode yang digunakan dalam kegiatan Pengabdian Kepada Masyarakat meliputi wawancara, sosialisasi, dan pelatihan. Wawancara digunakan untuk mengetahui permasalahan dengan mitra dan komunikasi dengan mitra tentangn pelaksanaan pengabdian kepada masyarakat. Metode wawancara ini dilaksanakan secara online melalui aplikasi Whatsapp. Metode sosialisasi dan pelatihan digunakan pada saat pelaksanaan pengabdian kepada masyarakat. Kegiatan ini dilaksanakan secara daring dengan menggunakan aplikasi Google Meet.

Kegiatan pengabdian kepada masyarakat dilaksanakan pada bulan September November 2020 secara daring menggunakan aplikasi Whatsapp dan Google Meet. Teknik pengumpulan data yang digunakan menggunakan lembar angket yang diberikan secara online menggunakan google form diberikan ke peserta pelatihan sebelum dan setelah pelatihan. 
Pelaksanaan kegiatan ini dilakukan dalam tiga tahap, yaitu tahap persiapan, pelaksanaan, dan evaluasi, seperti yang terlihat pada gambar 1. Tahap pertama adalah tahap persiapan. Dalam tahap ini tim melakukan survei pendahuluan untuk mengetahui kondisi target kegiatan dengan menganalisis kondisi tempat yang akan digunakan, kondisi peserta yang akan diberikan pelatihan, dan menyusun rancangan kegiatan yang akan dilakukan. Survey pendahuluan dilakukan secara online menggunakan aplikasi Whatsapp. Tahap kedua yaitu tahap pelaksanaan. Tim melakukan sosialisasi dan pelatihan pembuatan video animasi pembelajaran interaktif secara daring menggunakan Google Meet. Tahap ketiga adalah monitoring dan evaluasi. Evaluasi kegiatan ini dilakukan terhadap proses kegiatan. Evaluasi berkaitan selama kegiatan berlangsung dari tahap persiapan sampai tahap pelaksanaan, yang meliputi keadaan sekolah, kehadiran peserta pelatihan, antusias peserta saat mengikuti kegiatan, dan saran atau kritik terhadap kegiatan. Pada tahap ketiga juga dilakukan secara online menggunakan aplikasi Whatsapp.

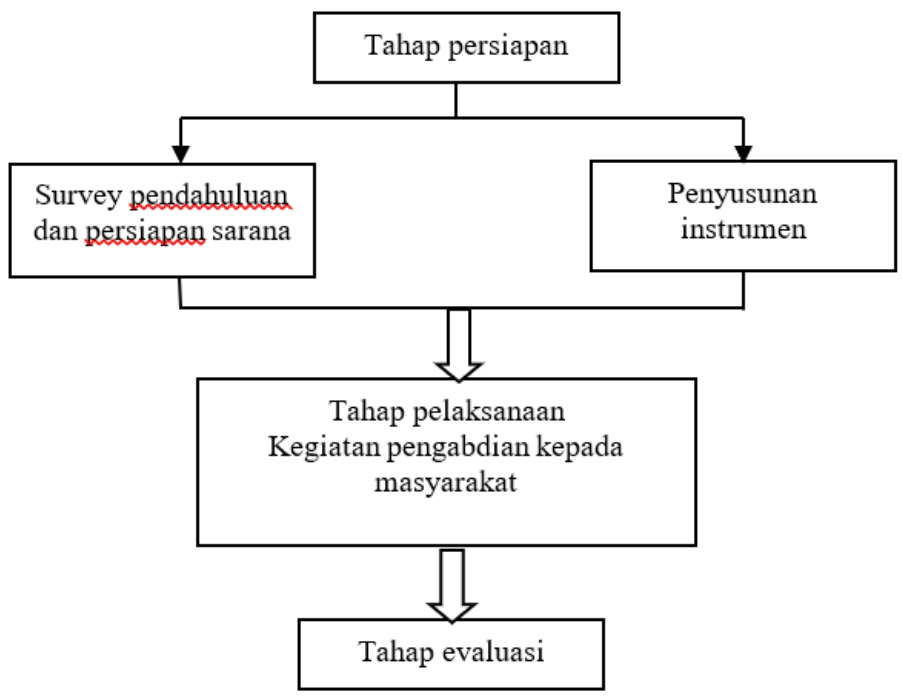

Gambar 1. Alur kegiatan pengabdian kepada masyarakat.

\section{HASIL DAN PEMBAHASAN}

Kegiatan pengabdian kepada masyarakat di SMK Paya Rumput Melaka Malaysia dalam kegiatan pelatihan pembuatan video pembelajaran dengan Powtoon yang telah terlaksana pada tanggal 21-22 September 2020 yang dilakukan secara daring dengan aplikasi Google Meet dapat memberikan inovasi pembelajaran bagi guru-guru di SMK Paya Rumput Melaka Malaysia. Pembuatan video pembelajaran dengan Powtoon merupakan salah satu inovasi dalam pembelajaran online di masa Covid 19 saat ini. Kegiatan ini diikuti oleh Bapak/Ibu guru SMK Paya Rumput Melaka Malaysia sebanyak 59 guru.

Powtoon merupakan suatu perangkat lunak pengolah media presentasi animasi berbasis SaaS (Software as a Service) yang dapat diakses secara online melalui situs www.powtoon.com yang dapat digunakan sebagai alat bantu presentasi bagi guru dalam melaksanakan proses pembelajaran di dalam kelas (Yulia \& Ervinalisa, 2017). Dengan menggunakan media pembelajaran yang dirancang dengan menggunakan perangkat lunak Powtoon secara online tersebut mampu menghasilkan sebuah media pembelajaran berbasis teknologi informasi dan 
komunikasi (TIK) untuk presentasi yang lebih menarik dan modern, karena media presentasi dapat dibuat dengan berbagai efek animasi kartun yang sangat unik dan menarik, selain itu kita juga dapat menambahkan serta menggabungkan berbagai gambar, teks, audio, video, serta berbagai data lainnya yang diperlukan dalam proses penyampaian materi pembelajaran kepada siswa (Al Farizi et al., 2019).

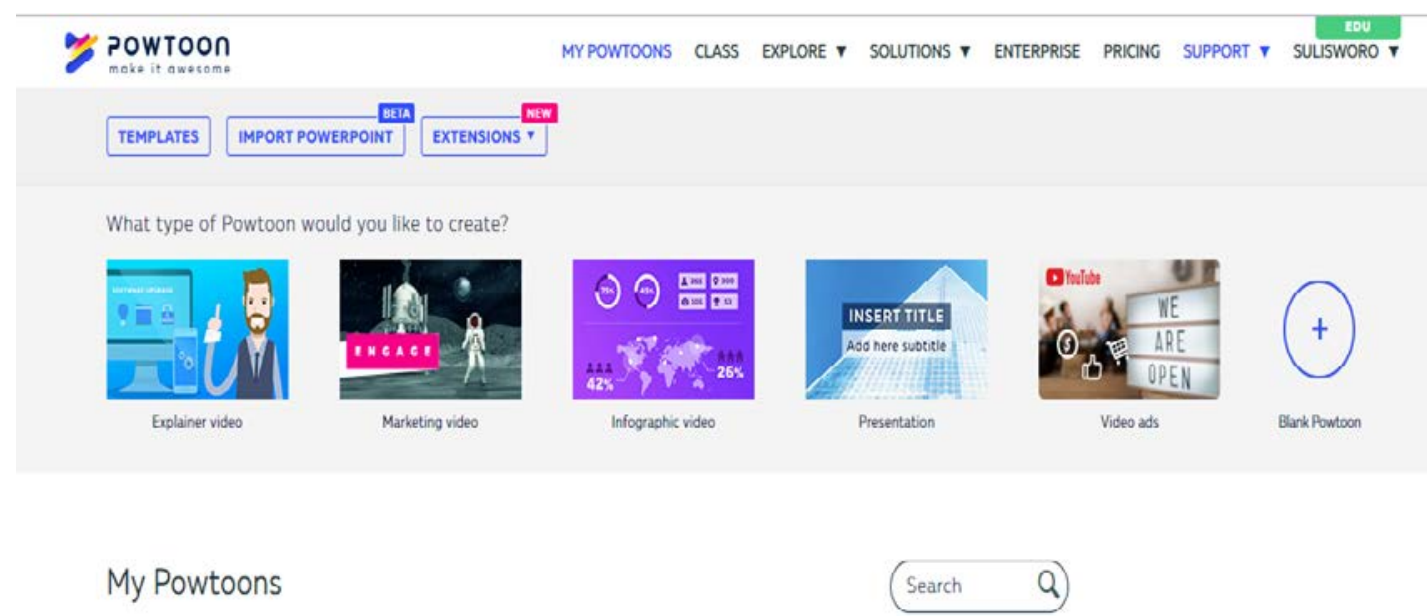

Gambar 2. Tampilan beranda Powtoon

Hasil dari kegiatan pengabdian kepada masyarakat di SMK Paya Rumput Melaka Malaysia yaitu yang pertama, dapat mengoptimalkan sarana dan prasarana yang tersedia, maka tim Abdimas memanfaatkan sarana dan prasarana dengan baik dengan cara memberikan sosialisasi tentang pemanfaatan sarana dan prasarana untuk menunjang proses pembelajaran dengan media pembelajaran interaktif dengan Powtoon.

Kedua, untuk mengatasi kelemahan guru dalam memanfaatkan teknologi dalam proses pembelajaran, maka kami tim abdimas melakukan pelatihan pembuatan video interaktif dengan Powtoon. Tujuan dari kegiatan ini adalah agar guru mampu video pembelajaran interaktif yang sederhana dan mudah digunakan dalam pembelajaran online.

Guru-guru di SMK Paya Rumput Melaka Malaysia sangat antusias ketika mengikuti kegiatan pelatihan video pembelajaran interaktif dengan Powtoon. Pada awal kegiatan pelatihan tim Abdimas memberikan survey yang berisi analisis kebutuhan guru dalam video pembelajaran. Hampir $88 \%$ guru belum pernah membuat video pembelajaran dengan Powtoon, $10 \%$ guru sudah mengetahui Powtoon tetapi belum pernah membuat video pembelajarannya. Pada saat pelaksanaan Abdimas, tim Abdimas memberikan sosialisasi mengenai video pembelajaran, kemudian dilanjutkan dengan praktek pembuatan video pembelajaran dengan Powtoon.

Kegiatan hari pertama tanggal 21 September 2020 diawali dengan Sambutan oleh perwakilan tim Abdimas yang disampaikan oleh Dasmo, M.Pd. Kemudian setelah itu sosialisasi mengenai media pembelajaran oleh Yoga Budi Bhakti, M.Pd. Pada hari kedua tanggal 22 September 2020 dilakukan kegiatan pelatihan praktek pembuatan video pembelajaran interaktif dengan Powtoon oleh Irnin Agustina Dwi Astuti, M.Pd. 


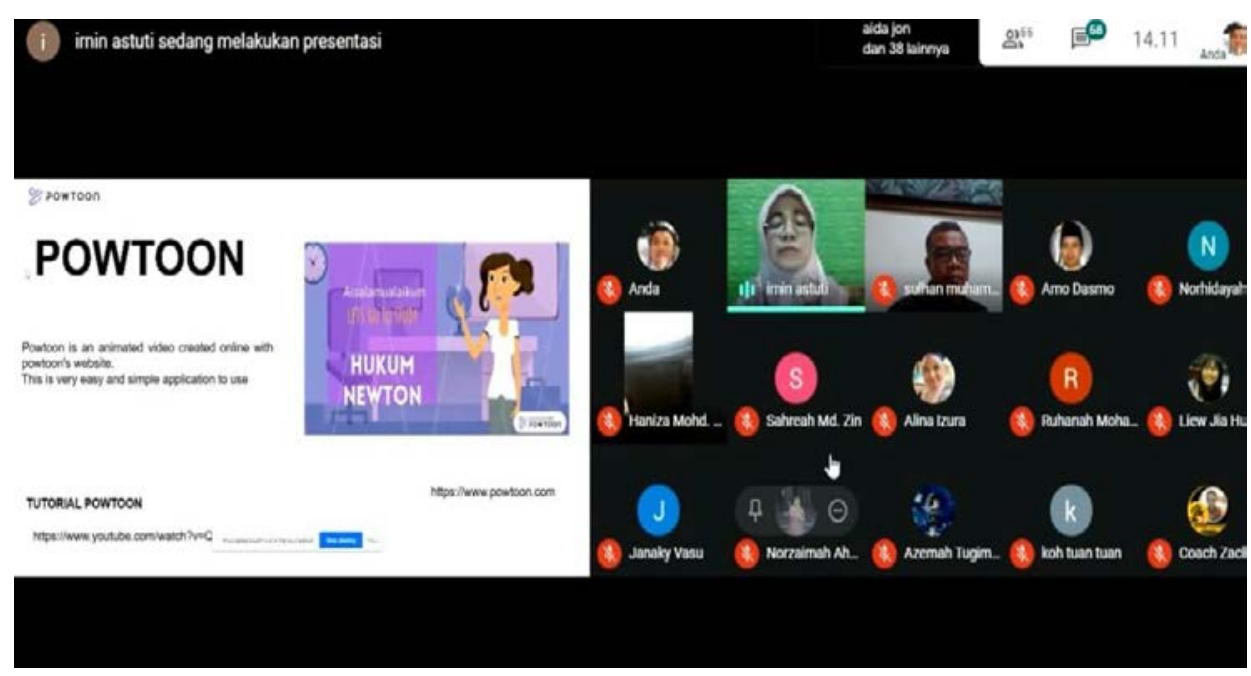

Gambar 3. Pelatihan video pembelajaran dengan Powtoon

Setelah kegiatan pelatihan selesai, di akhir kegiatan tim memberikan angket respon peserta dalam kegiatan pelatihan. Berdasarkan analisis data menunjukkan respon yang positif mengenai kegiatan Abdimas. Berdasarkan gambar 4 menunjukkan bahwa kemampuan guru-guru meningkat dalam pembuatan video animasi pembelajaran. Sebelum pelatihan guru-guru jarang membuat video pembelajaran, Sebagian besar mereka hanya menggunakan video pembelajaran mililk orang lain yang di share ke siswa. Berdasarkan analisis angket yang dibagikan ke guru, diperoleh nilai kemampuan guru dalam pembuatan video animasi pembelajaran sebelum pelatihan sebesar $38 \%$ dan setelah pelatihan sebesar $77 \%$, terlihat pada gambar 4 . Dengan adanya kegiatan pelatihan pembuatan video animasi pembelajaran ini kemampuan guru dalam membuat video animasi pembelajaran dengan Powtoon naik sebesar $39 \%$, dengan kategori tinggi.

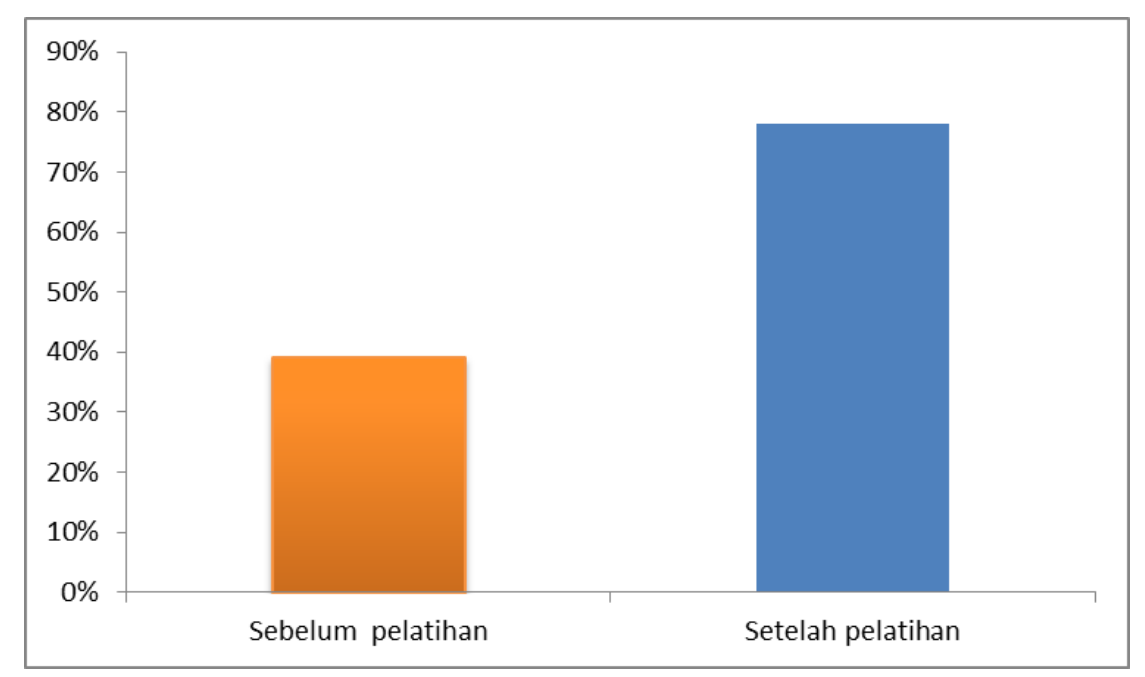

Gambar 4. Peningkatan kemampuan guru dalam membuat video animasi pembelajaran

Sejalan dengan penelitian Hardiyanti menyatakan dengan pelatihan pembuatan video pembelajaran, guru-guru menjadi lebih percaya diri dan termotivasi menggunakan teknologi, guru dapat merancang dan membuat video animasi pembelajaran sederhana yang menarik sesuai tema dan kebutuhan anak, serta guru dapat merancang video interaktif dan melibatkan anak 
dalam pembelajaran (Hardiyanti et al., 2020). Pembuatan video pembelajaran menjadi salah satu alternatif media pembelajaran yang mudah dibuat oleh guru.

Setelah pelaksanaan kegiatan pelatihan pembuatan video pembelajaran kemudian kegiatan selanjutnya adalah monitoring dan evaluasi. Kegiatan monitoring dilakukan dengan menggunakan Whatsapp grup untuk berkonsultasi dan mengumpulkan video pembelajaran karya dari guru-guru SMK Paya Rumput Melaka. Dalam kegiatan monitoring masih ada beberapa guru yang belum menyelesaikan pembuatan video pembelajaran karena keterbatasan waktu. Mereka berharap kegiatan seperti ini bisa berlanjut di semester depan untuk belajar media pembelajaran lagi. Saran dan kritik dari peserta pelatihan yaitu membutuhkan 3-4 pertemuan untuk kegiatan pembuatan video pembelajaran dengan Powtoon.

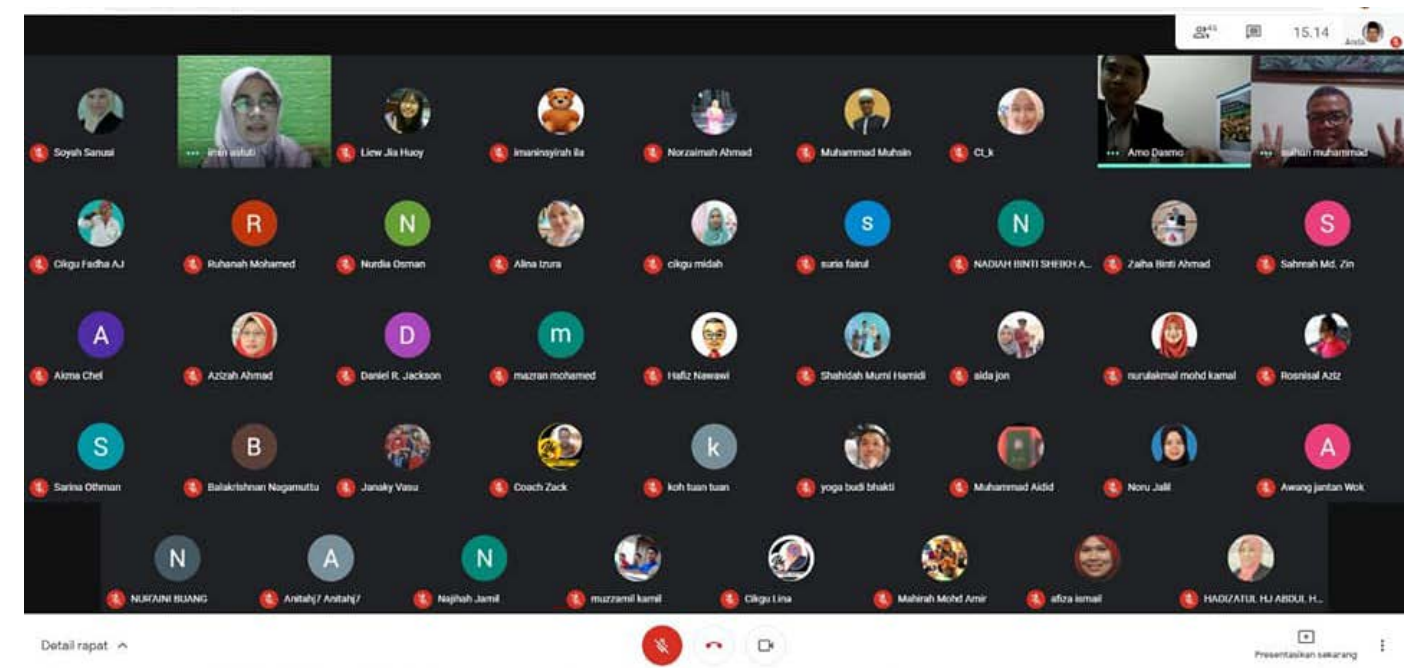

Gambar 5. Peserta kegiatan abdimas

Video pembelajaran merupakan penunjang seorang guru dalam memberikan materi ke siswa. Apalagi dalam kondisi Covid 19 saat ini pembelajaran yang dilakukan secara online, guru harus membuat suatu inovasi media pembelajaran agar siswa tidak bosan belajar selama di rumah. Video pembelajaran merupakan salah satu inovasi media pembelajaran yang bisa digunakan saat pandemi Covid 19 (Pujiasih, 2020). Guru dituntut harus meiliki kemampuan berkreasi dalam membuat media pembelajaran. Sejalan dengan pendapat penggunaan Nuzuliana, video pembelajaran dalam pembelajaran fisika dapat membantu siswa dalam memahami konsep fisika terutama video yang terkait dengan aplikasi konsep yang dipelajari (Nuzuliana et al., 2015). Video pembelajaran dapat menjadi penunjang belajar siswa secara mandiri, terlebih lagi di kondisi pembelajaran daring saat ini. Dengan menggunakan video pembelajaran siswa dapat mengulang-ulang materi pembelajaran dengan cara menontonnya sehingga memudahkan siswa dalam emmahami materi (Sumarni et al., 2020).

Kegiatan pelatihan pembuatan video pembelajaran yang laksanakn oleh guru-guru dapat mengubah kreativitas guru dalam membuat video pembelajaran yang interaktif (Herayanti et al., 2019). Guru masih membutuhkan kegiatan-kegiatan yang berupa pengembangan diri atau profesionlitas diri untuk mempersiapkan seorang guru yang mampu mengembangkan bahan aar dan media pembelajaran (Astuti et al., 2019). Selain dapat mendukung proses pembelajaran, juga 
dapat meningkatkan kredibilitas sekolah karena telah menggunakan media video dalam proses pembelajaran, serta meningkatkan kemampuan guru dalam hal pengembangan media berbasis video (Rahmi \& Cerya, 2019).

\section{KESIMPULAN}

Pengabdian kepada masyarakat di SMK Paya Rumput Melaka Malaysia berjalan dengan baik sesuai dengan hasil kuisioner umpan balik tingkat kepuasan mitra dalam pelaksanaan pengabdian kepada masyarakat yang mengatakan bahwa mitra memberikan respon yang positif dengan kegiatan Abdimas ini. Kuisioner umpan balik terhadap kepuasan proses memperoleh hasil setuju dengan kegiatan Abdimas ini. Berdasarkan analisis data diperoleh peningkatan guru dalam pembuatan video animasi pembelajaran dengan Powtoon sebesar $39 \%$. Dengan mempunyai bekal dalam pembuatan video animasi pembelajaran diharapkan guru mampu mengimplementasikan dan menggunakan video animasi pembelajaran sebagai media pembelajaran selama pembelajaran online agar dapat menarik siswa untuk belajar dan dapat meningkatkan motivasi belajar siswa. Saran guru agar kegiatan ini dapat berjalan terus dengan berbagai jenis pengabdian lainnya. Guru berharap selalu ada inovasi terbaru untuk meningkatkan kegiatan pembelajaran di sekolah sehingga dapat meningkatkan kemampuan guru dan juga meningkatkan prestasi belajar siswa.

\section{DAFTAR PUSTAKA}

Al Farizi, Z., Sulisworo, D., Hasan, M. H., \& Rusdin, M. E. (2019). Pengembangan Media Animasi untuk Mendukung Pembelajaran Berbasis TPACK dengan POWTOON pada Materi Torsi SMA Kelas XI. Jurnal Penelitian Pembelajaran Fisika, 10(2), 108-113. https://doi.org/10.26877/jp2f.v10i2.4017

Asmuni, A. (2020). Problematika Pembelajaran Daring di Masa Pandemi Covid-19 dan Solusi Pemecahannya. Jurnal Paedagogy: Jurnal Penelitian Dan Pengembangan Pendidikan, 7(4), 281-288. https://doi.org/10.33394/jp.v7i4.2941

Astika, R. Y., Anggoro, B. S., \& Andriani, S. (2019). Pengembangan video media pembelajaran matematika dengan bantuan powtoon. Jurnal Pemikiran Dan Penelitian Pendidikan Matematika (JP3M), 2(2), 85-96.

Astuti, I. A. D., Sumarni, R. A., \& Bhakti, Y. B. (2019). Pengembangan multimedia interaktif berbasis Lectora Inspire sebagai Media Pembelajaran Guru. Abdimas Dewantara, 2(2), 107-114. https://doi.org/10.30738/ad.v2i2.2872

Atsani, K. H. L. G. M. Z. (2020). Transformasi media pembelajaran pada masa Pandemi COVID-19. AlHikmah: Jurnal Studi Islam, 1(1), 82-93.

Awalia, I., Pamungkas, A. S., \& Alamsyah, T. P. (2019). Pengembangan media pembelajaran animasi Powtoon pada mata pelajaran matematika di kelas IV SD. Kreano: Jurnal Matematika Kreatif-Inovatif, 10(1), 49-56. https://doi.org/10.15294/kreano.v10i1.18534

Gumanti, R. W. (2020). Inovasi Pendidikan Dalam Efektivitas Penerapan Kurikulum 2013. Syntax Imperatif: Jurnal Ilmu Sosial Dan Pendidikan, 1(4), 189-202. https://doi.org/10.36418/syntax-imperatif.v1i4.47

Hardiyanti, W. E., Ilham, M., Ekadayanti, W., \& Jafarudin, J. (2020). Pelatihan Pembuatan Video Animasi Gambar "Powtoon" bagi Guru PAUD. Abdimas Pedagogi: Jurnal Ilmiah Pengabdian Kepada Masyarakat, 3(2), 78-86. https://doi.org/10.17977/um050v3i2p78-86

Herayanti, L., Safitri, B. R., Sukroyanti, B. A., \& Putrayadi, W. (2019). Pelatihan Pembuatan Video Pembelajaran Bagi Guru-guru di SDN 1 Ubung dengan Memanfaatkan Bandicam. Jurnal Pendidikan Dan Pengabdian Masyarakat, 2(4), 495-500. 
Martha, Z. D., Adi, E. P., \& Soepriyanto, Y. (2018). E-book berbasis Mobile learning. Jurnal Kajian Teknologi Pendidikan, 1(2), 109-114.

Munir. (2015). Multimedia Konsep dan Aplikasi dalam Pendidikan. Alfabeta, CV.

Nuzuliana, A. H., Bakri, F., \& Budi, E. (2015). Pengembangan Video Pembelajaran Fisika Pada Materi Fluida Statis di SMA. Prosiding Seminar Nasional Fisika (E-Journal), 4, 67-73.

Pujiasih, E. (2020). Membangun generasi emas dengan variasi pembelajaran online di masa pandemi covid19. Ideguru: Jurnal Karya Ilmiah Guru, 5(1), 42-48. https://doi.org/10.51169/ideguru.v5i1.136

Purandina, I. P. Y. (2020). Pendidikan Karakter Tumbuh Selama Pandemi Covid-19. In COVID-19: Perspektif Pendidikan (Vol. 3, Issue 2, p. 99). Yayasan Kita Menulis.

Rahmi, E., \& Cerya, E. (2019). Upaya Peningkatan Kompetensi Pedagogik Guru SMK Bisnis Manajemen Kabupaten Agam Melalui Pelatihan Pembuatan Video Pembelajaran. Amaliah: Jurnal Pengabdian Kepada Masyarakat, 3(2), 314-320. https://doi.org/10.32696/ajpkm.v3i2.284

Solviana, M. D. (2020). Pemanfaatan Teknologi Pendidikan di Masa Pandemi Covid-19: Penggunaan Gamifikasi Daring di Universitas Muhammadiyah Pringsewu Lampung. Al Jahiz: Journal of Biology Education Research, 1(1), 1-14.

Sumarni, R. A., Bhakti, Y. B., Astuti, I. A. D., Sulisworo, D., \& Toifur, M. (2020). The Development of Animation Videos Based Flipped Classroom Learning on Heat and Temperature Topics. Indonesian Journal of Science and Mathematics Education, 3(3), 304-315. https://doi.org/10.24042/ijsme.v3i3.7017

Yulia, D., \& Ervinalisa, N. (2017). Pengaruh Media Pembelajaran Powtoon Pada Mata Pelajaran Sejarah Indonesia Dalam Menumbuhkan Motivasi Belajar Siswa IIs Kelas X Di SMA Negeri 17 Batam Tahun Pelajaran 2017/2018. Historia: Jurnal Program Studi Pendidikan Sejarah, 2(1). https://doi.org/10.33373/his.v2i1.1583 